Historic, archived document

Do not assume content reflects current scientific knowledge, policies, or practices. 
62,37

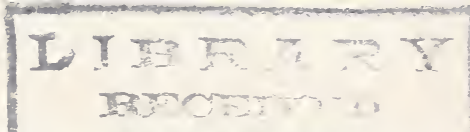

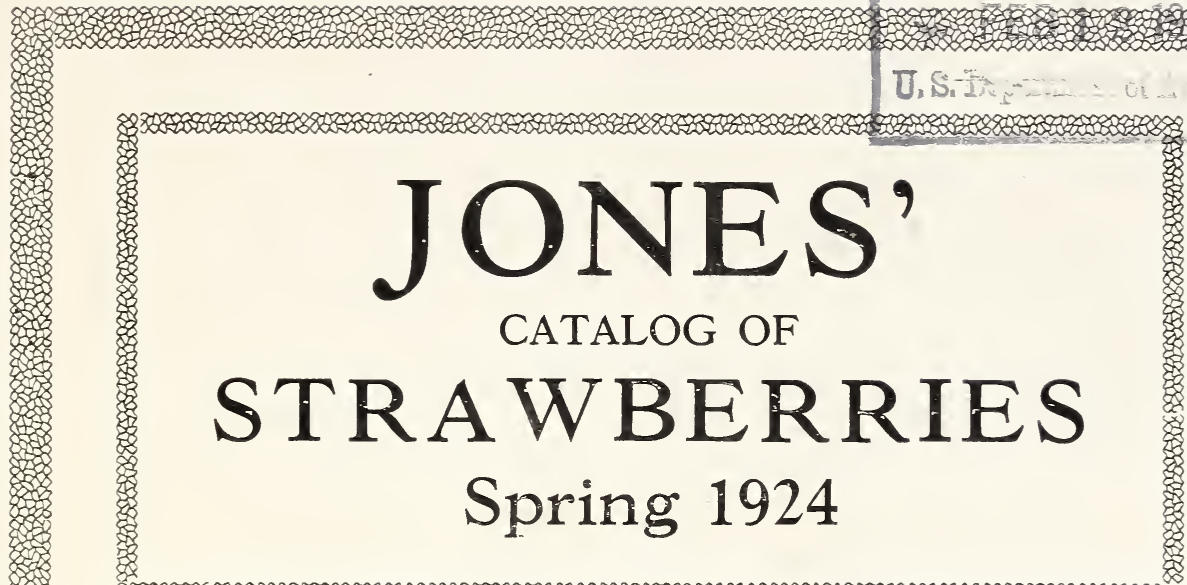

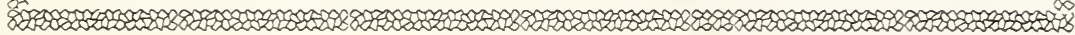

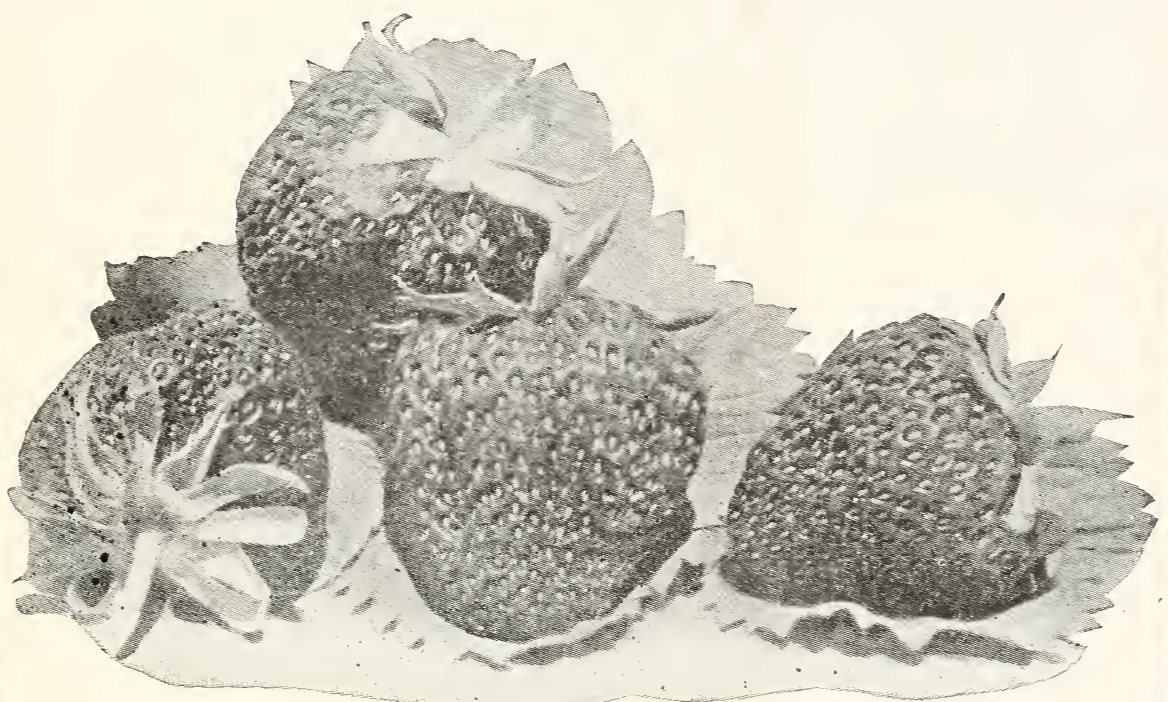

J. W. Jones \& Son Co.
Allen, Maryland

SELECTED PLANTS OF THE BEST VARIETIES OF STRA WBERRIES

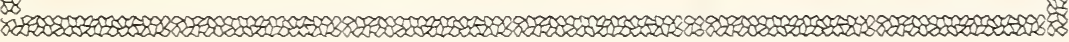




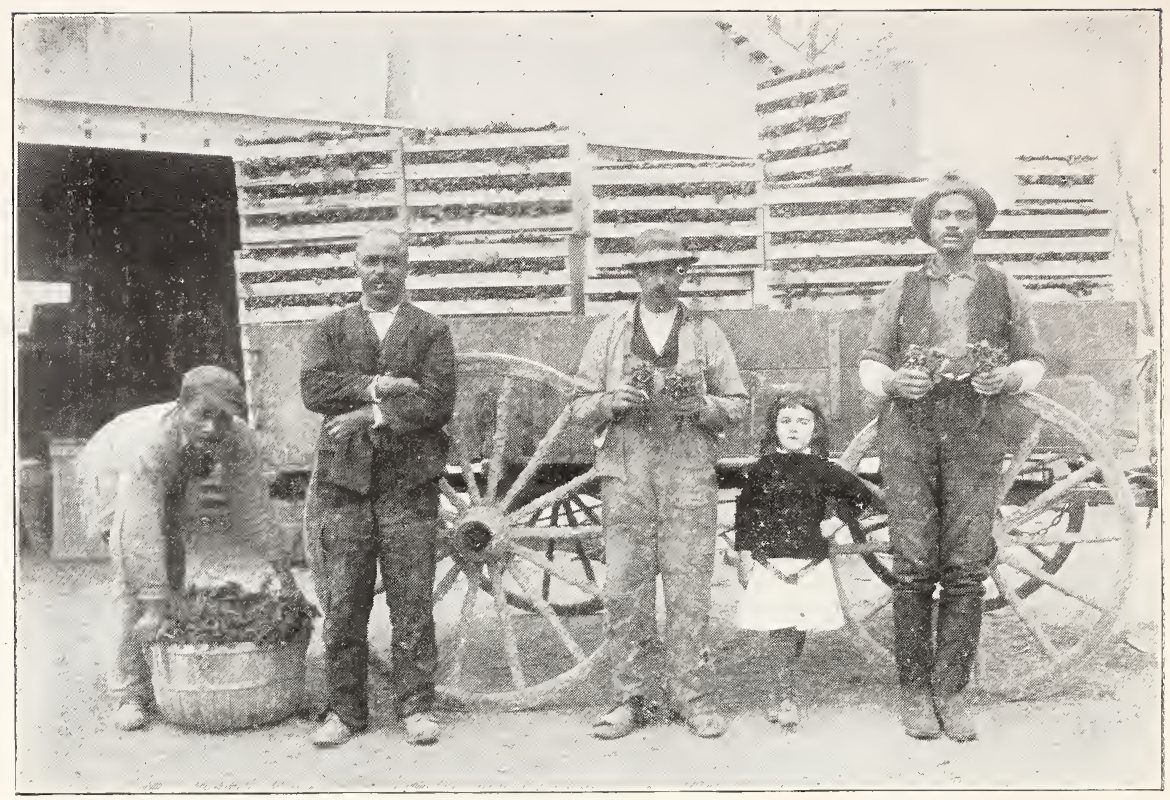

$A$ load of our plants packed ready for shipment

\section{What We Will Agree to Do}

We sell by catalog only, and to everyone at the same price, filling all orders with the same high-grade stock. Strawberry plants frequently can be shipped during warm spells in winter, and after March 1 in unlimited quantities. From then until May 1 we are busy every day filling orders for customers. After May 1 we can fill a limited number of orders, but at purchaser's risk always.

We Ship Out Only Fresh-dug Plants and will replace free of charge anything that reaches you in bad order, provided the transportation companies have given the shipment reasonable dispatch. If it has been unreasonably long on the way, the purchaser should examine it and, if spoiled, decline to receive it and make claim on express company.

Our Terms are Cash with Order, and please remember when you are sending your money in advance that every one else is doing exactly the same thing. We will, of course, book orders, and hold them a reasonable length of time awaiting remittance.

Remit by Bank Draft, Check, Post-Office or Express Money Order or Registered Letter. Your personal check preferred.

As to Our Responsibility, we refer you to the Peoples National Bank of Salisbury, Maryland. In writing it, please inclose stamp for reply.

\section{J. W. JONES \& SON CO., Allen, Md.}




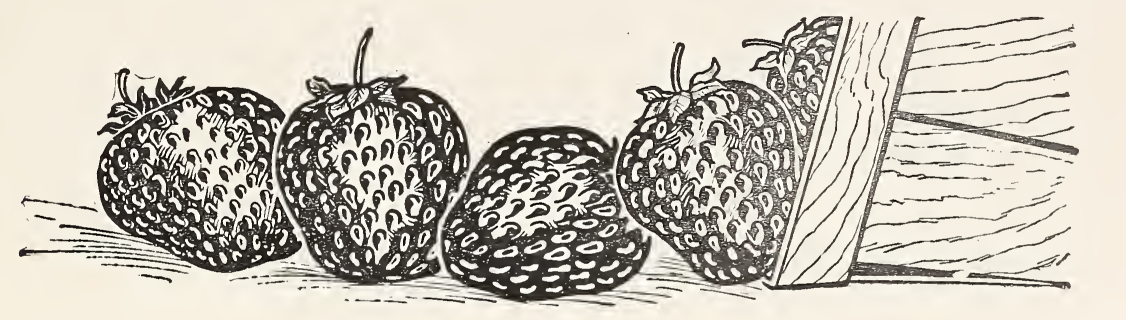

\section{4}

\section{To Our Friends and Customers}

7 HE season of 1923 was distinguished by the largest business that our firm has ever done. We shipped more plants and to a

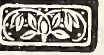
larger number of customers than ever before. This goes to show that our plants are giving satisfaction and that our business methods are correct.

For this season we have an unusually large and fine stock of plants. As fine as we have ever grown and nearly as large.

We feel sure that we shall be able to take care of all orders that come to us and with plants of our own growing.

We are constantly being asked as to the future of the berry business-whether it is about to be overdone or not. We always answer that we do not believe the growing of real high grade strawberries will be overdone. It seems to us that the available supply of labor for the farm now must ever remain so small that it will be impossible to "glut" the market with strawberries as once we did. They cannot be worked and they cannot be picked in the enormous acreages that once they could. The future production of strawberries in America has permanently passed into the hands of the small grower-and we do not believe, that he will over do it.

Let us thank all our friends, especially, those old friends, who have stood with us so loyally through the years and wish them all a very happy and prosperous year.

J. W. JONES \& SON CO. 


\section{How We Grow Strawberries}

Every year we have numberless requests for information on the best method of growing Strawberries. Of course, every one recognizes that this is a very difficult question to answer, as conditions vary so greatly in different localities and on different soils. Nine-tenths of all berries grown, or even more, are grown by the matted-row system; that is, to leave about all the runners on the parent plants to take root and make a wide row, leaving enough room in the alley between the rows for the convenience of the pickers.

The fundamental element of success in growing of any crop is the selection of a soil. Strawberries need a strong, well-drained location, but, at the same time, the land should be as retentive of moisture as it is possible to have it. Strawberries suffer from dry w+ ather more often than from any other cause and, therefore, a moist soil always contributes to success. Here we always grow cowpeas on land the year previous to planting Strawberries; where they are not practicable, sow rye in the early fall and plow under early the next spring, as Strawberries need a soil full of humus. It holds the moisture and makes them grow and bear.

We always plow in the fall, but when that cannot be done, plow as early in the spring as possible. This is important, as berry plants need a well-compacted soil. Settling during the winter puts the soil in ideal condition for spring planting.

Make your rows $3 \frac{1}{2}$ to 4 feet apart and set plants from 15 inches to 3 feet apart in the rows, depending on the variety. Chesapeake,

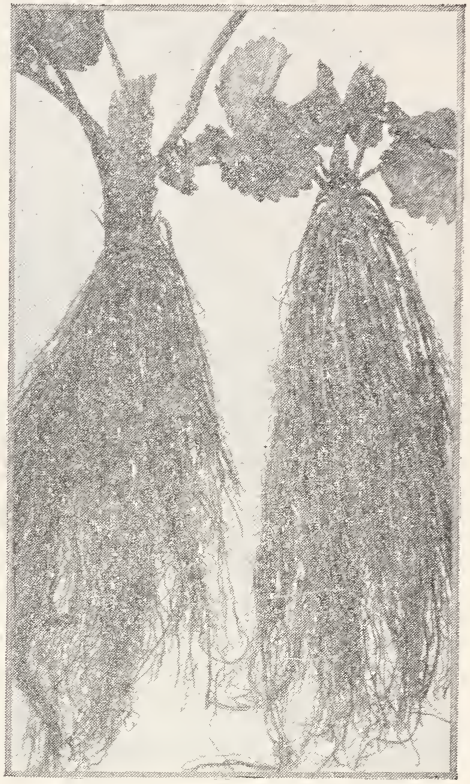

The roots of our Strawberry plants making few plants, should be placed about 15 inches. Dunlap, a prolific plantmaker, will get too thick quite often if set 3 feet. Haverland, Ekey and most midseason kinds will usually make a proper bed if planted 3 feet apart. Gandy, 2 to $2 \frac{1}{2}$ feet. We run our furrows with a double row marker, sow fertilizer down the furrow at the rate of 400 to 500 pounds to the acre, and then make a sharp list with a one-horse turning plow; strike this down nearly to the level of the field with a hoe, or small drag, and you are ready to set your plants.

We desire to warn our friends against the too heavy application of commercial fertilizers to young Strawberry plants. It is dangerous in the extreme. Many plants have been injured and often killed outright, but 400 or 500 pounds will not hurt them, provided it is well scattered and then cultivated in before setting plants.

There are many methods of setting the plants. We use a two-horse transplanter, but no particular method has advantage over any other except in the saving of labor. The important thing is to get your plants in the ground the same depth as they grew in the original bed, and to pack the dirt firmly around the roots. This done, there is little choice as to the method of doing it. The cultivation is always important and should be started as soon as planting is finished. If one will take the trouble to destroy all grass and weeds the year previous on land to be planted to Strawberries, it will be found to pay handsomely, as the seeds thus destroyed will not be in your berry-beds to plague the grower and run up the cost of hoeing. Keep them clean until frost, hoe shallow so as not to disturb the roots, and success is assured. 


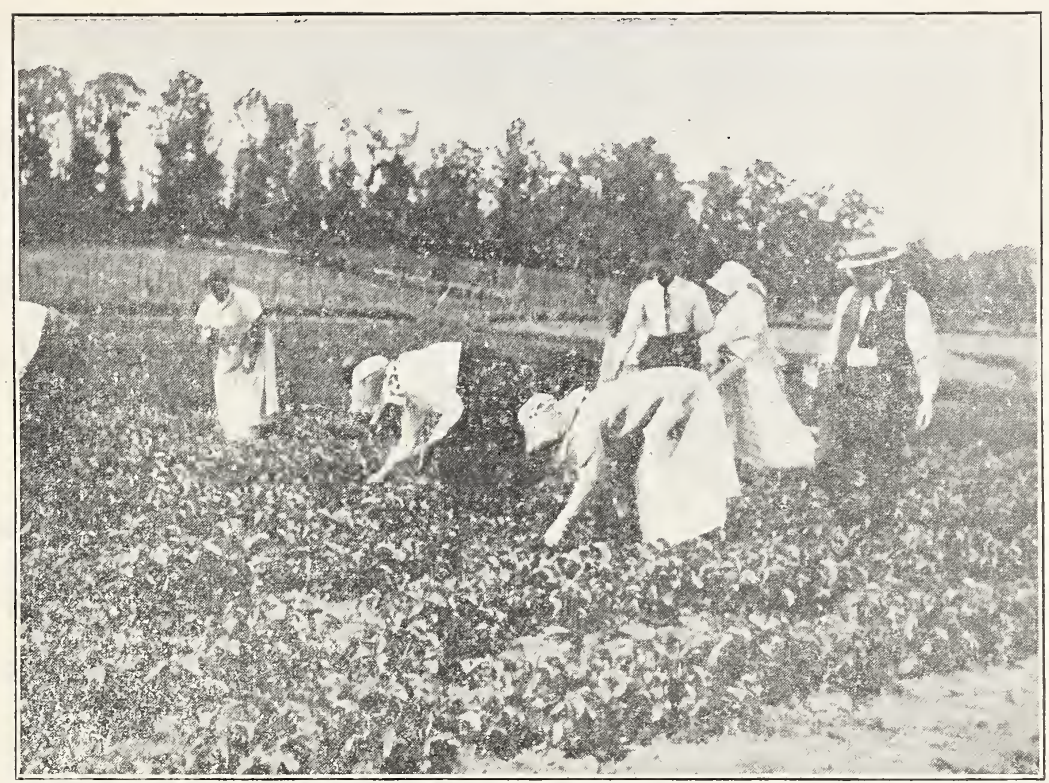

Berry picking time

\section{Something About Soils That Are "Strawberry Sick"}

Every berry grower of extensive experience has found that frequently his berry plants refuse to grow. As a rule he has erroneously attributed this to disease in the plants, especially if they were purchased, rather than propogated by himself. Experiments have convinced many growers that the real trouble is in the soil itself; that there are certain places where it is practically impossible to grow berries successfully. Whether this refusal on the part of berry plants to grow in these given places is due to the lack of a certain bacteria or plant food, or whether the soils contain some poison that kills the plant is a moot question as yet, and one that a number of our State Experiment Stations are now at work on.

Our life-long experience in growing Strawberries has taught us, however, that a number of kinds are practically immune from trouble on any soil, while there are others that have to planted on favorable soils or they refuse to grow. In order that our friends may have the benefit of our experience we propose to call attention to those kinds that refuse to grow in some places, and also to the kinds which will grow anywhere.

We have found Chesapeake particularly susceptible to soil poison; Klondyke, Parsons' Beauty, and Gandy also display a weakness in this direction. Big Joe, on the contrary, will grow anywhere and hold up the crop-while Ekey, Haverland, Sample, Premier, Aroma, and First-Quality are ideal, scarcely ever showing any weakness. Wm. Belt, Glen Mary, Dunlap and Abington are medium, not doing so well on all soils as Haverland, Sample, and Aroma, but are rnuch surer everywhere than Chesapeake and the others named in that class. 


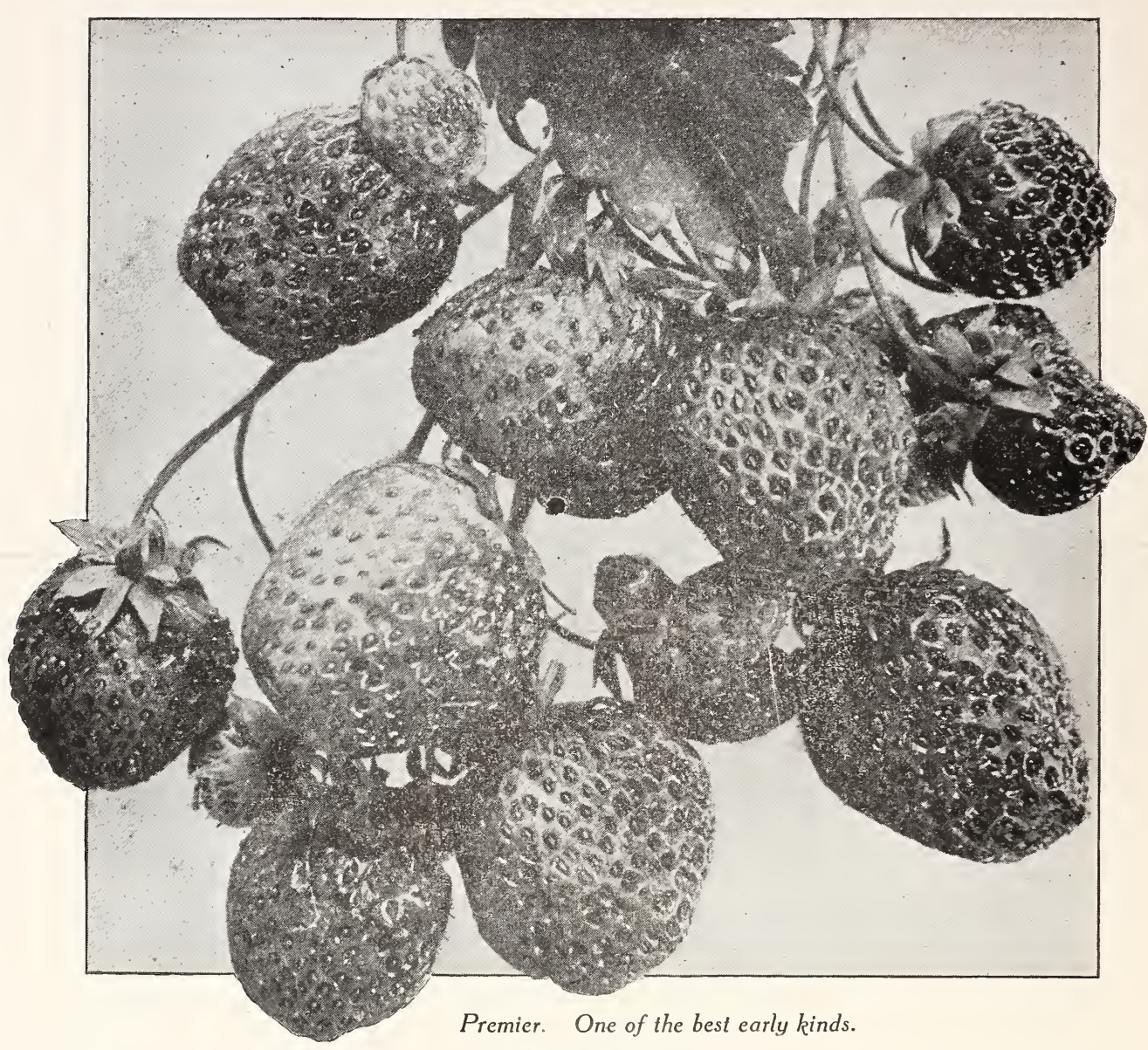

PREMIER

Of all berries ever introduced Premier seems to be more nearly ideal than any we have ever seen. It is beyond all question the best early variety ever offered the American public. For several years now in spite of manifold adverse conditions it has produced enormous crops and they have brought the highest market price always. In 1921 and ' 22 when frost swept out all other early kinds Premier came through with a full crop. In other years when other kinds were failing on account of lack of moisture Premier was still on the job. It is a good grower, making plenty of stocky heavily rooted plants, but not inclined to get too thick; you always have a bed that is just about right. It is tremendously productive of good sized berries, bearing a strong resemblance to Haverland, and no matter how many kinds there are in the market Premier always tops them all in price. The most remarkable feature is the fact that it keeps so well; for three or four days after picking it holds up in texture and appearance to a most remarkable degree. It does not matter where you may live we can recommend Premier, as reports from all sections agree in placing it at the head of the list and our prediction is that it will remain there a long time. If in doubt plant Premier. 


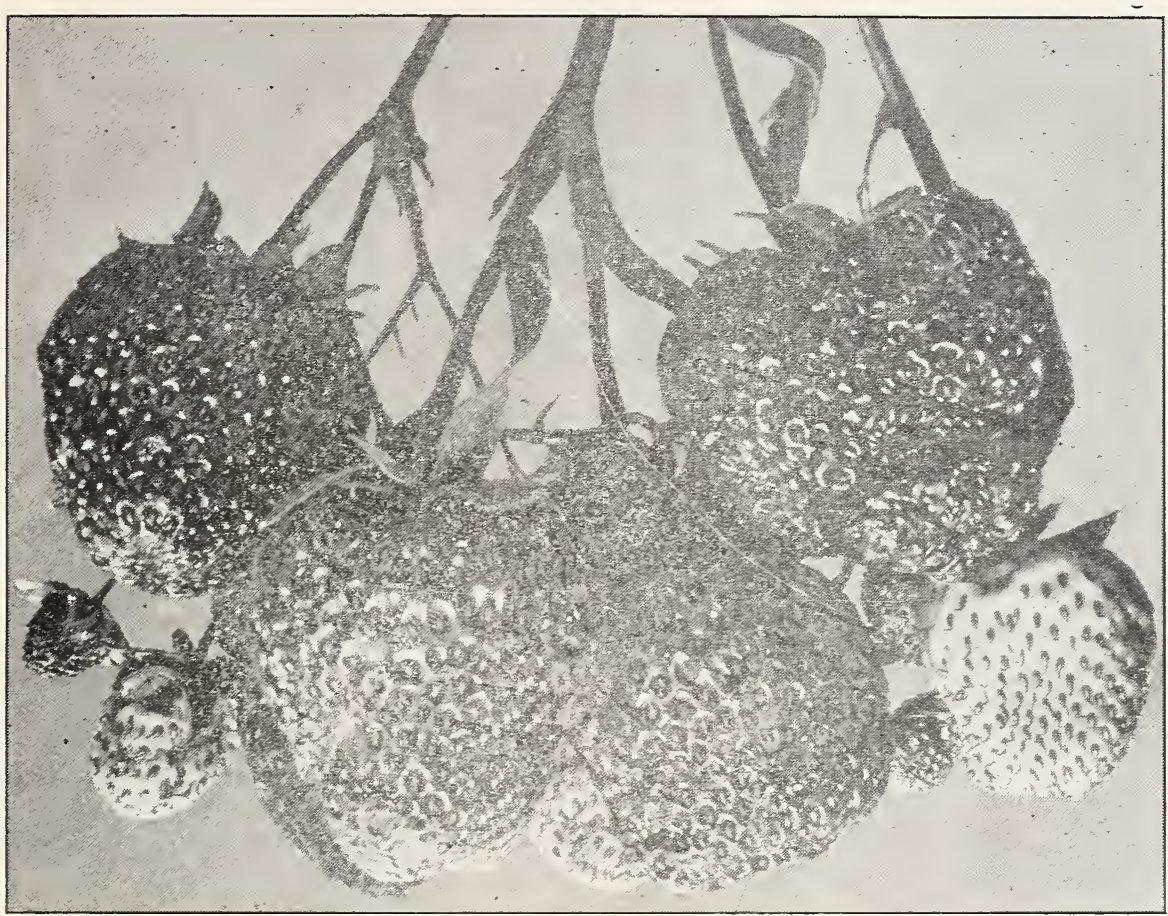

Chesapeake Strawberries

\section{Abington}

A good, strong grower in plant, making enough runners for a good bed; berries large and fine looking. A good seller and a heavy bearer, you may plant Abington with confidence. Ripens midseason, and comes on quickly. Its only weakness seems to be lack of firmness. This is a description written three or four years ago and is correct according to our test; however, Abington does not seem to be popular and we do not especially recommend it.

\section{Paul Jones}

One of the most productive varieties on the entire list. On all soils, light or heavy, rich or poor, it brings the crop. It is a good, vigorous grower, making plenty of plants. It has an imperfect blossom and should be planted with Big Joe, Aroma or Dunlap. Berries large, good appearance and ship well. If you want a great crop plant Paul Jones.

\section{AROMA}

There are a few Strawberry varieties that "run out" quickly; there are a few others that "hold their own" for a long time; but Aroma seems to be one that improves with age. It has really been growing steadily better here ever since we first grew it. Grows better, bears better and sells immensely better than ever before. It ripens with the regular midseason kinds, such as Haverland and Sample. It is every bit as good a seller as the Gandy, being quite as large, firm and handsome as that well-known standard of shipping excellence; on any kind of dry soil will bear twice the quantity of berries as Gandy. In fact we do not know of any kind that holds up better on dry, thin soils than Aroma. It is also a good sure grower in nearly every locality and on all kinds and conditions of 


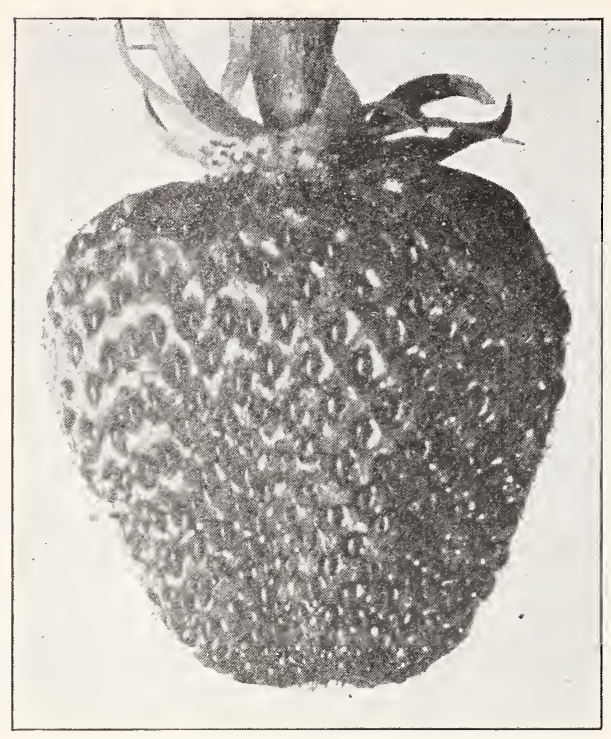

Aroma Strawberry

soils, for while the plants are not so large as many others, for toughness and vigor it has no superior. But the biggest thing in its favor is its selling quality. On all the Middle West markets Aroma is always quoted at from 25 cts. to $\$ 1$ per crate higher than average varieties, which in a season of overproduction means a lot. Our own experience leads us to recommend it as a good pollenizer, though it has not usually been recommended for that purpose. We have found it better than Chesapeake, for it is much more vigorous in growth. Certainly in the Middle West no grower can make a mistake in planting Aroma.

\section{BIG JOE}

On the back cover page of this cata$\log$ will be seen a photograph of a cluster of this most remarkable berry. The berries were picked here on May 24, mailed to Harrisburg, and the photograph made on the 26 th, so it must ship fairly well. This picture will give some idea of the wonderful productivedess of this berry, as it is not in the least exaggerated and that single cluster contains fourteen berries. In size it is the equal of anything we have ever seen, taking the entire crop right through, as the last berries are almost as large as the first; and this in spite of the fact that it bears as many quarts as any kind we have ever seen. It ripens midseason, along with Haverland and Sample, comes on rapidly and ripens all over at once, making it easy to pick. The shipping quality is about equal to Bubach, Haverland or Sample, we would say. It is not so firm as Aroma or Gandy, but it has shipped well from this section for a number of years and has brought the very highest prices ever paid for any kind in the history of the berry deal here. We have known of many instances where a whole crop of Big Joe brought 15 cents a quart at the loading station. It is also a particularly strong and vigorous grower; the equal of Haverland at its very best. We feel sure that it meets every possible requirement of the market berry-grower, being productive, a strong and healthy grower, and has a perfect bloom, so that it does not require a pollenizer. In fact, we think it can be used as a pollenizer for any of the midseason varieties. For lots of big red berries that bring the money, plant Big Joe, as every report we have ever had from it spoke enthusiastically in its praise.

\section{Campbells Early}

From New Jersey, which has the honor of have given many valuable berries to the public. It is classed as the best early variety grown in "Jersey". It is a good strong grower, makes plenty of plants and seems to be healthy in every way. We have a small stock of plants which we are offering at a reasonable price. We sold all our plants of this last spring but it is a good early variety when the frost does not get it. 


\section{CHESAPEAKE}

The most valuable of all of W. F. Allen's introductions. For many years there has been a place for a fancy late berry of good shipping qualities and Chesapeake has filled it. We have never seen any that was of more beautiful appearance; large, even in shape and uniform in size, it seems to have reached perfection so far as market qualities are concerned. Ripens a little earlier than Gandy, but holds out about as long, and in most. localities is vastly more productive, though Gandy may occasionally, with ideal soil, bear quite as many berries as Chesapeake. The great superiority that it has over nearly all others is its remarkable selling qualities, for we have positively known of sales where it brought twice as much per quart as other standard varieties of its season, and last year it sold for more than the Gandy the season through. It may be that there will be an over-production of poor berries, but we doubt if there will ever be too many of such high quality and handsome berries as Chesapeake. Its only weakness is a difficulty in getting a bed of the plants.

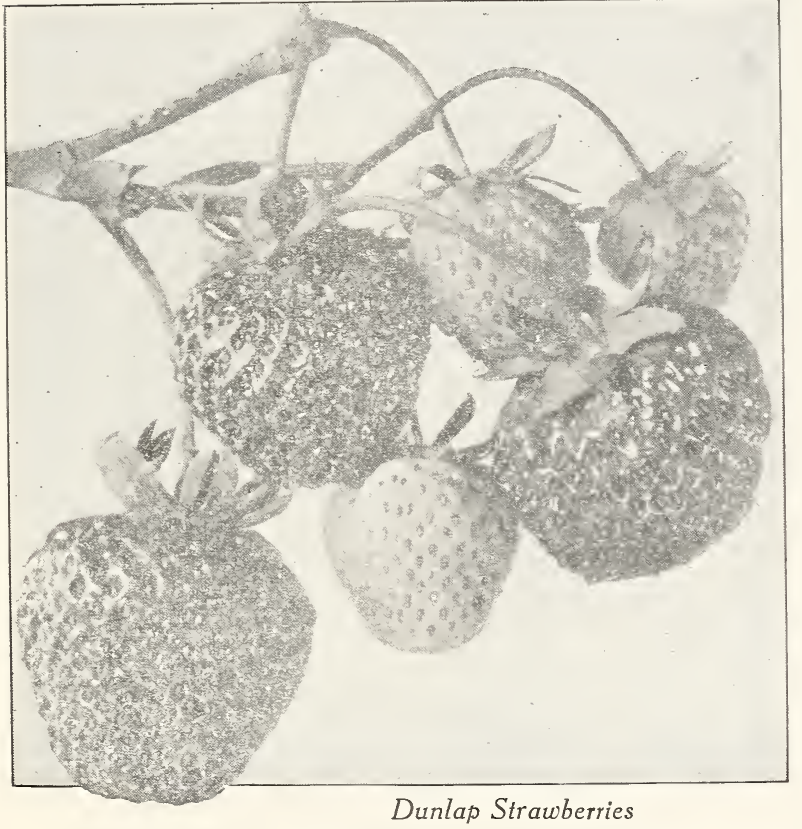

\section{Dunlap}

Makes more plants than any that we grow, and if allowed to get too thick the berriesare generally small; but, when properly thinned, you find it hard to get a berry that will produce more nice market berries than Dunlap. Has become the standard for pollenizing such varieties as Cardinal, Haverland and Warfield. The fruit is average in size and perfect in shape and ships well, but the great point with Dunlap is that it maybe depended on to grow well and bear well everywhere and every time, even during a record-breaking drought. Ripens with the very earliest midseason berries and matures its crop rapidly.

We Guarantee everything that we sell true to name, and believe 99 per cent of everything that we have ever shipped has proved so. However, sometimes in spite of the utmost precautions, mistakes do occur, and we will, upon proper proof, replace anything that proves untrue to label or refund the purchase price.

Strawberry Plants are packed in slatted crates, with plenty of damp moss, and will carry as far as from any concern in the United States.

There is not a Stranberry in this book we cannot recommend fully. 


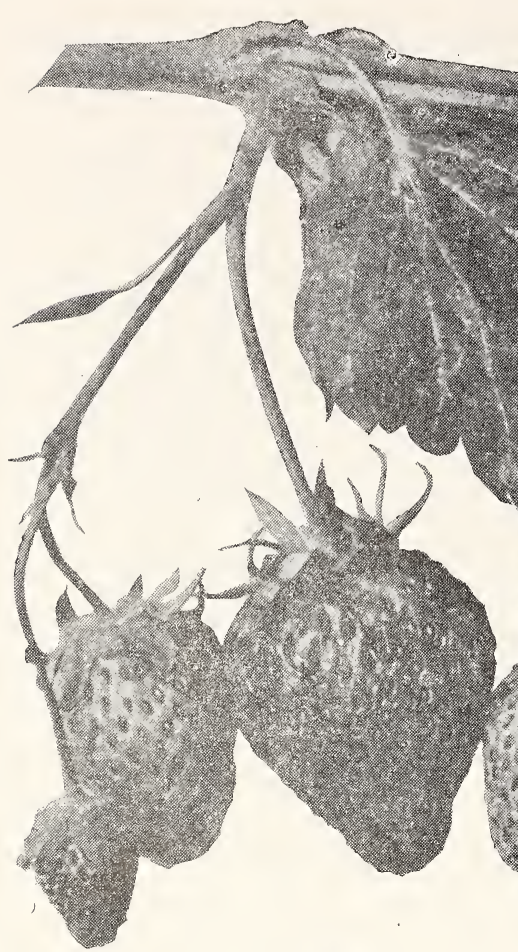

\section{Ekey}

For many years we unhesitatingly recommended this as one of the very best berries in the mid-season ripening period, and with us it has always done well. However it has not proved generally popular and we do not recommend it unless you have tested it out on your soil. It is a splendid grower, making just enough strong-rooted plants for a perfect matted row. There is no sign of rust on them, their dark green foliage being marked in any field where they are grown. It is tremendously productive; we believe that it is equal in this respect to any we have ever grown, and it has the advantage of ripening the entire crop during the first few days of the season. It is also a splendid shipper and keeper, and will always command the highest market price.

\section{FIRST-QUALITY -}

This was for many years a very popular variety but it seems to be "running out' as all berries eventually do. It is a good grower and the berries are fine looking and large, and it is quite productive. We still think it a good one for strong soils especially as a pollenizer for Haverland.

\section{Gibson}

Not especially recommended for a shipping berry but fine for local market or home use. Berries large, beautiful dark red color, vigorous grower and very productive. Bears through a long season and very popular for canning.

Send us $\$ 1.50$, and we will send postpaid to any post office in the U.S., 100 plants of Progressive, the great Fall-bearing Strawberry. 


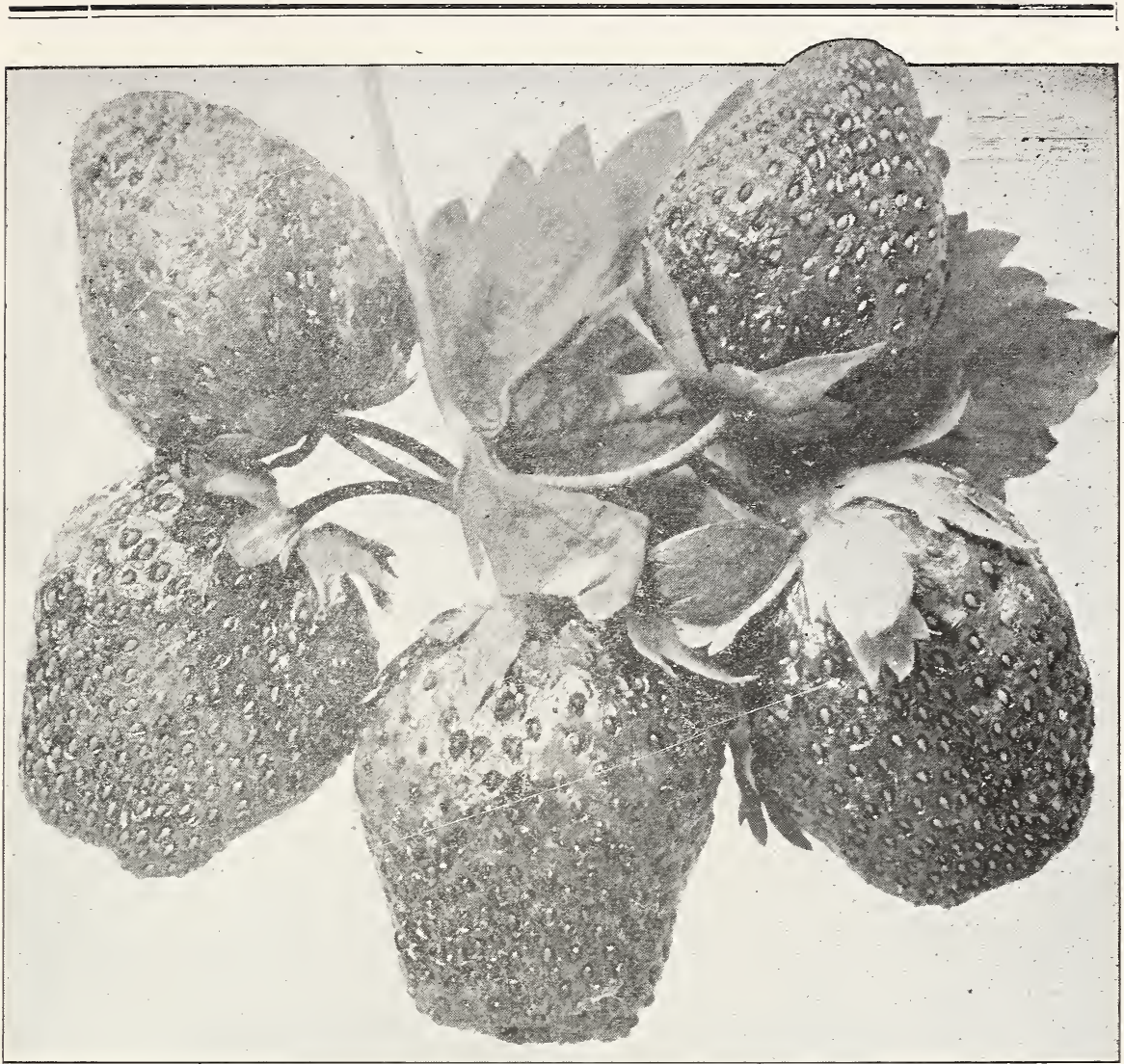

Haverland Strawberries

\section{Glen Mary}

This has for several years now been a standard for number of quarts produced wherever it does well. It has an inclination to rust in many places, which makes it impossible to grow it successfully, but in the North it is certainly one of the leaders. One of the strongest points in its favor is the very vigorous grow th that it always makes. While not a persistent runner, it yet makes plenty of the largest, stockiest plants that one can imagine. The berries are large to the very largest, but not always of the best shape; neither is it a good shipper; but, where one has a home market, and is sure that Glen Mary will not rust, we can recommend it with every confidence that it will fill the bill. Its time of ripening, the earliest of the mid-seasons, makes it very valuable, and its exquisite flavor makes it one of the most desirable Strawberries especially for the home garden.

We sell by catalog only, and to everyone at the same price, filling all orders with the same high-grade stock. Strawberry plants frequently can be shipped during warm spells in winter, and after March 1 in unlimited quantities. From then until May 1 we are busy every day filling orders for customers. After May 1 we can ship a limited number of orders, but at purchaser's risk always. 


\section{GANDY}

For twenty years the leading late kind and by many still considered the best. The only trouble is, that on dry soil or in a very dry season it cannot be depended on to bear well. Of extraordinary shipping and selling qualities, it is still the leading market berry for late in all important berry-producing centers, and we annually sell plants of it well up toward the 500,000 mark, the most indisputable evidence of its widespread popularity. A free plant-maker and a good grower generally, yet sometimes failing in vigor; it is easy to grow, and its remarkable firmness makes it keep on the vines longer than almost any kind we know, and it never fails to bring the price.

\section{HAVERLAND}

It is a heavy yielder; and can be depended upon to bring up a crop every season-hot or cold wet or dry.

For 80 cts. we will send, postpaid, 50 plants of the famous Progressive Strawberry.

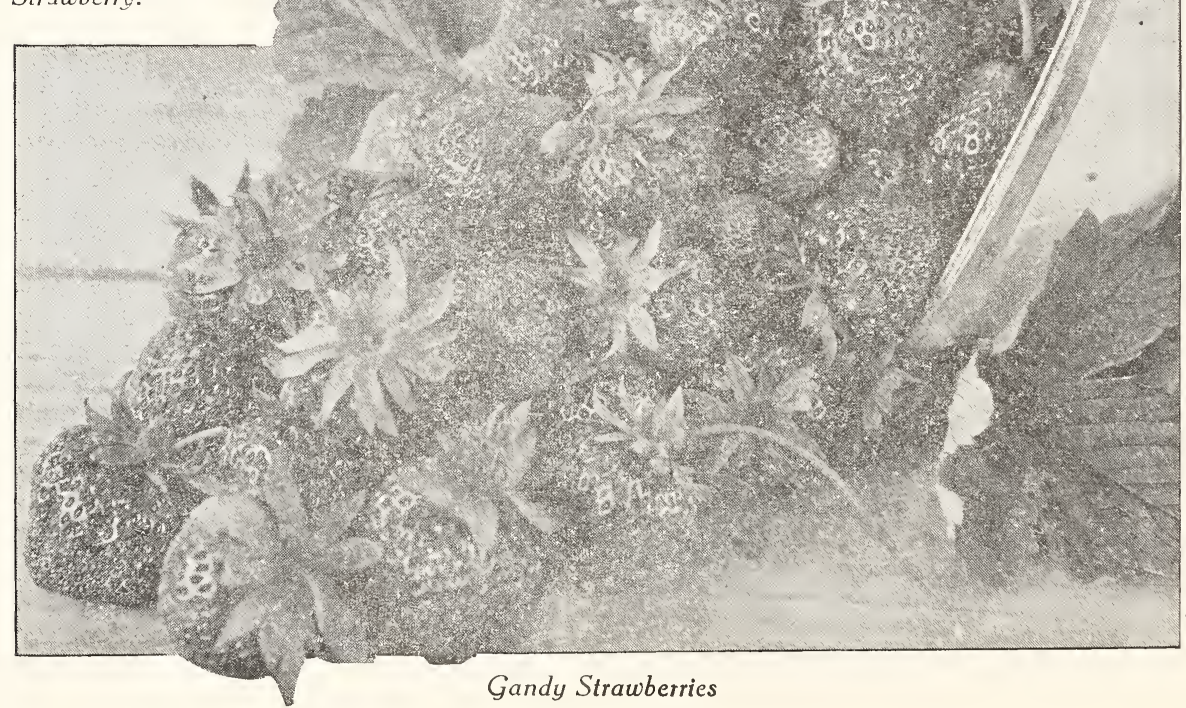

If you have any berries at all, you are sure to have Haverland; it is one of the toughest and strongest growers that there is on the list, and it is nearer frost-proof than any variety in cultivation, if not the nearest. These four points have combined to make it one of the most desirable berries for the average grower there is, and the fact that the sales on this more than thirtyyear-old kind are constantly increasing is proof that it is greatly appreciated. The berries are large to very large, long-conical, fairly firm and a good shipper, and it never rusts. There have been times when many other kinds were "all in" from drought and heat, Haverland was picking a fine crop. If in doubt, plant Haverland, and we know you will not be disappointed. 


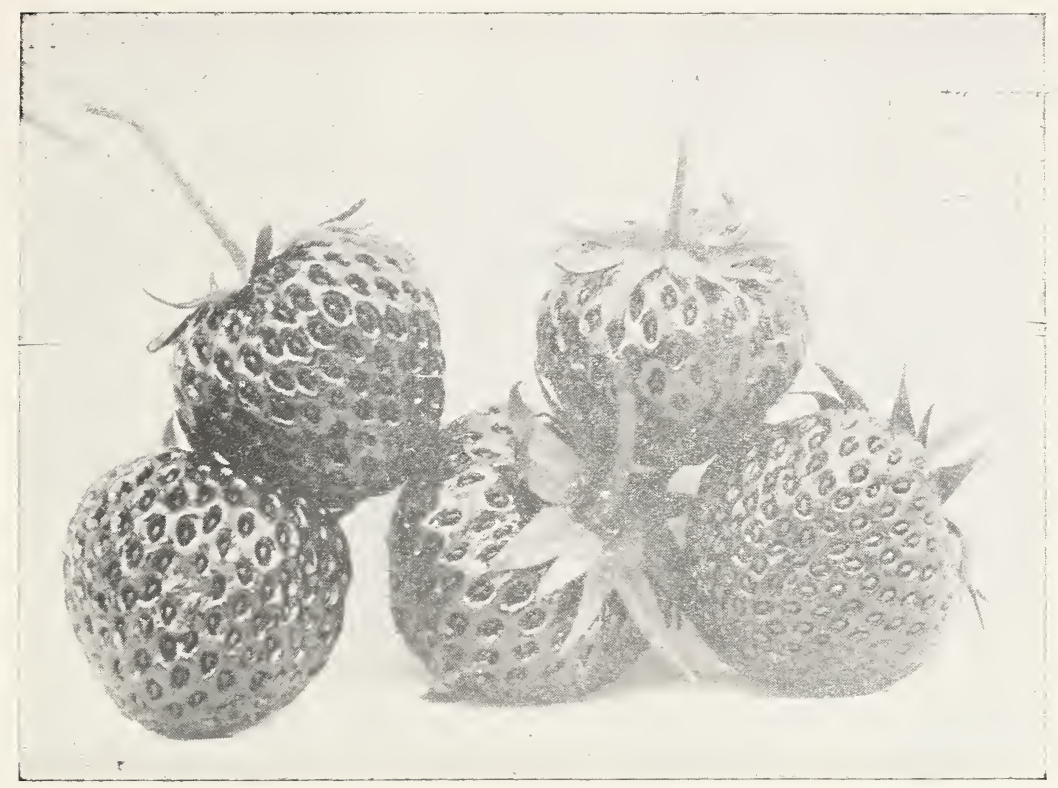

Klondyke Strawberries

\section{Klondyke}

Found valuable, not for the quantity of fruit that it produced, but from the fact that what it bore was of such fine appearance and shipping quality that it would command the top of the market always. It has a strong. staminate blossom which we think will make it satisfactory as a pollenizer. It is not tremendously productive, but bears a very fair crop, and the berries are remarkably uniform in size, shape and appearance, and of extra-fine quality. It begins to ripen about three days after the earliest kinds and continues in bearing through a long season.

\section{A bout Stock By Mail}

The parcel-post system does not make a lower rate on nursery stock than the regular merchandise rate; it is therefore prohibitive in cost except for short distances. For instance, the rate in the 6 th zone is $8 \mathrm{cts}$. per lb., which is too high, unless one is remote from express office, or wants only a light package. We can mail Strawberry plants in almost any quantity by making a number of different packages of the order, as follows:

On 12 and 25 plants: add 6 cts. for zones $1,2.3$ and 4 and 8 ets. for zones 5 , 6 and 7. Postage must be inclosed in your order in addition to the price.

On 50 plants: for zones 1,2 and 3 , add 8 cts.; for zone 4, 11 cts.; for zone 5 , 14 cts.; for zone 6,17 cts.

On 100 plants: for zones 1, 2 and 3, add 10 cts.; for zone 4, 19 cts.; for zone 5,25 cts.; for zone 6,33 cts.

On 250 plants: for zones 1 and 2, add 14 cts.; for zone 3, 24 cts.; for zone 4, $43 \mathrm{cts}$; for zone 5, $62 \mathrm{cts}$.; for zone 6, 81 cts.

On 500 plants: for zones 1 and 2, add 24 cts.; for zone 3, 44 cts.; for zone 4, 83 cts.; for zone 5, $\$ 1.22$; for zone $6, \$ 1.61$. 


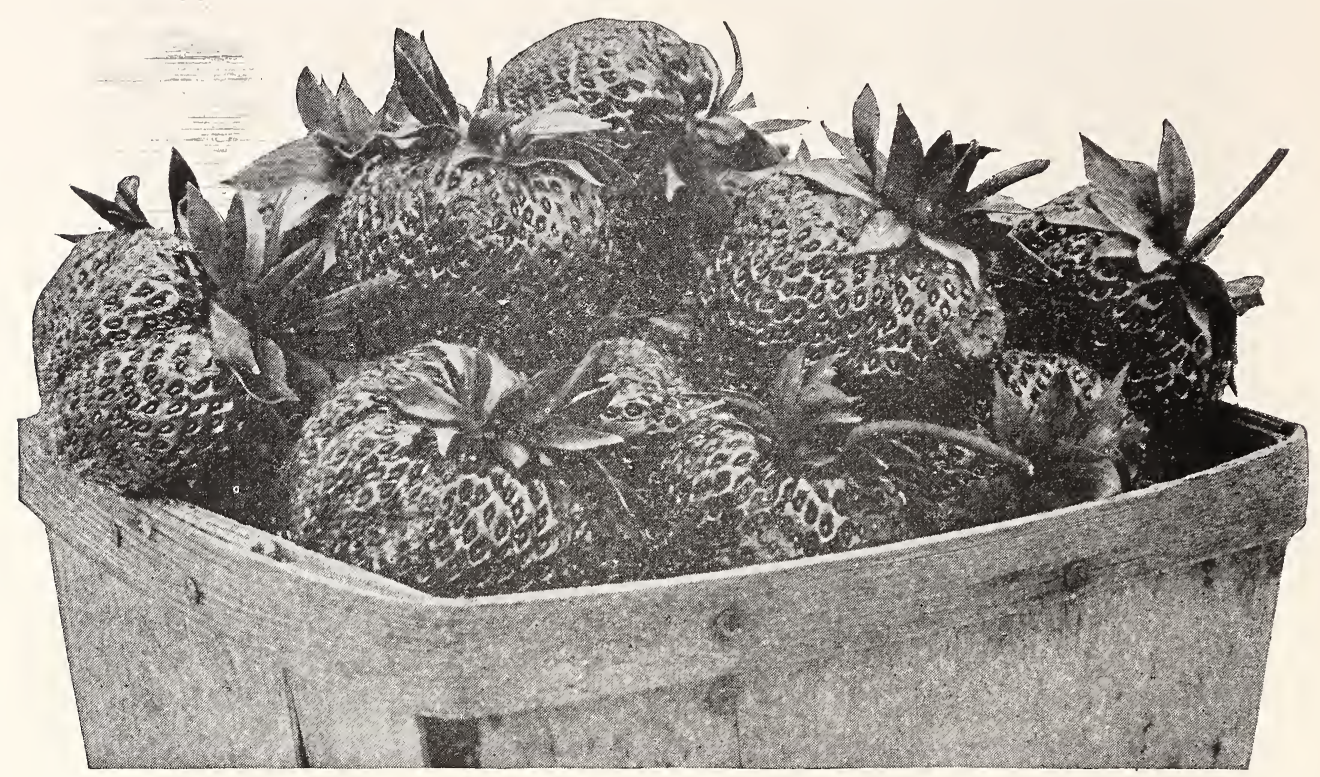

Lupton Strawberries

\section{Improved Heflin}

This is a candidate for public favor from Accomac County, Virginia, and it has certainly made a wonderful record there. It is extra early in time of ripening, large, fine cooking and very productive. At Onley, Virginia, headquarters for the Eastern Shore of Virginia Produce Exchange, last season 27 carloads of this variety were loaded one day. If you want something extra early try Improved Heflin.

\section{LUPTON}

To the man who wishes to grow really fancy berries we unhesitatingly recommend the Lupton. It is every whit as handsome as the justly famous Chesapeake, and is so much superior to that kind in vigor of plant growth that we urge all who have a fancy trade to supply to at least give Lupton a trial. The fruit is very firm and extremely handsome; in fact we do not know of any kind in existence today that shows up to better advantage when crater; and it is as productive as any kind we have ever grown that was a real fancy berry. It is a perfect flowering kind and is suitable for pollenization purposes if needed-ripening early midseason. It is not a rampant maker, but has never failed to make a good bed for us and the plants are heavily rooted and full of vigor. We say again if you want a strictly fancy berry plant Lupton, but we do not advise that it be planted on any but a good, rich soil.

\section{McAlpin}

One of the greatest growers we have ever seen, doing well on light poor soil, in fact will grow anywhere. It is a fine shipper and brings the top of the market. Very productive of medium to large, scarlet colored, perfectly formed berries and unsurpassed in quality. We recommend McAlpin to all who want a vigorous growing, productive and fine looking strawberry. It is a good onemedium late.

\section{Parsons' Beauty}

This is a tremendously productive berry of the Haverland and Tennessee type, and while it does not do its best every season, still we know it to be one of the best for size and a crop that can be planted. We do not recommend it, however, except for a moist, swampy soil of fair fertility; but, when given that, it is one of the greatest berries ever grown, provided the season is not too wet at picking time. If there is much rain when they are ripening they are sure to rot badly. 


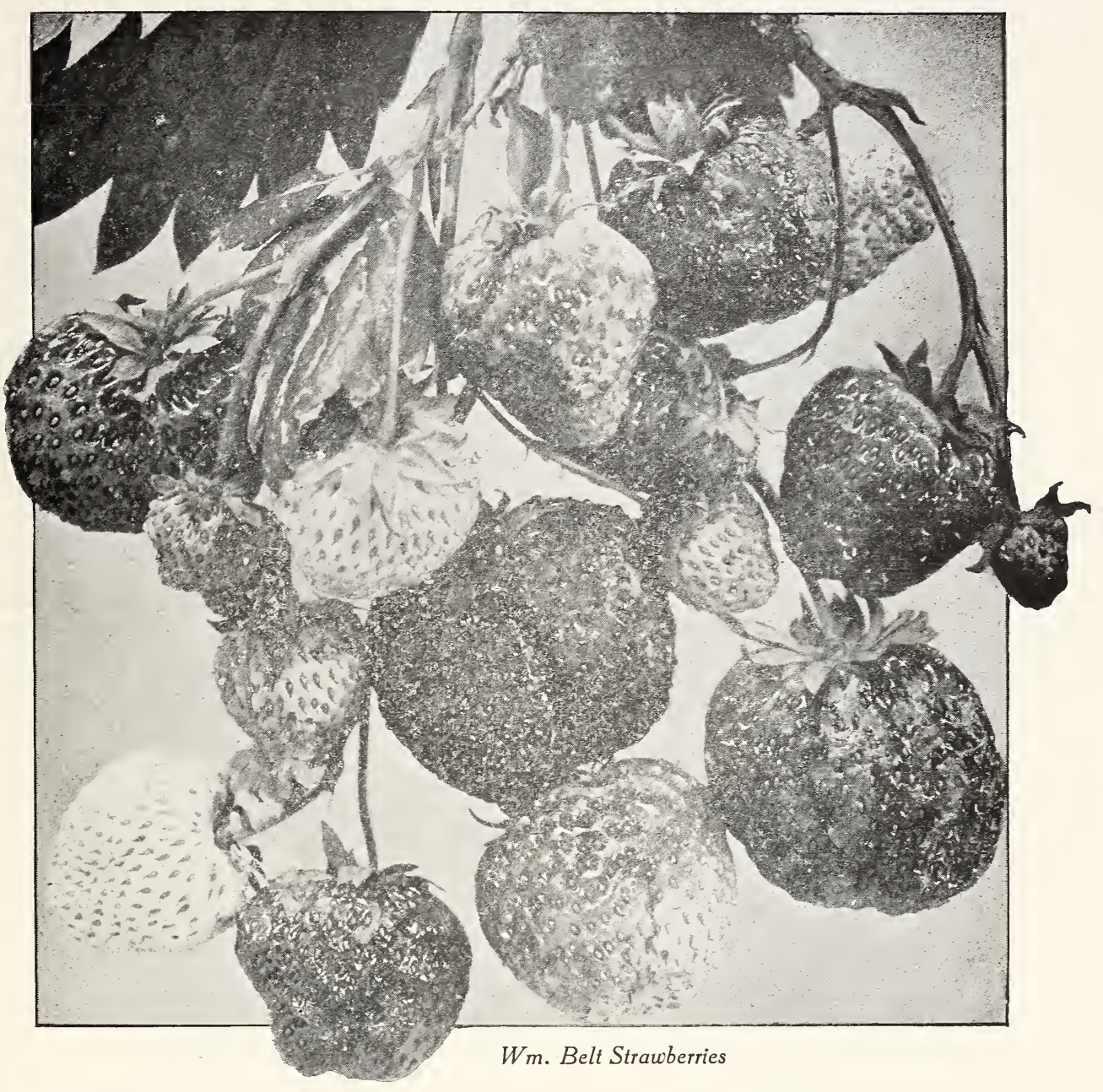

\section{SAMPLE}

Like the Aroma, this is better than when we first grew it. It used to rust some at picking time quite often, but for a number of years now it has been one of the healthiest and strongest growers we have. It is a beautiful grower, making just enough plants for an ideal fruiting-bed; and for productiveness it is not excelled by anything ever introduced. It is not likely that there is another sort that will bear as many quarts of berries as Sample. They are of a beautiful bright red, firm enough to ship any reasonable distance, and the quality and appearance are good enough to bring top prices always. The season of ripening is medium, about the same as Bubach or Haverland, and there is none that holds up better in size to the end of the season. Anyone wanting to plant maincrop berries would do well to include Sample in their list. It is reliable, especially in Pennsylvania and the Middle West. Big Joe and Sample make a great pair. If you want lots of big red berries. Plant them together. 


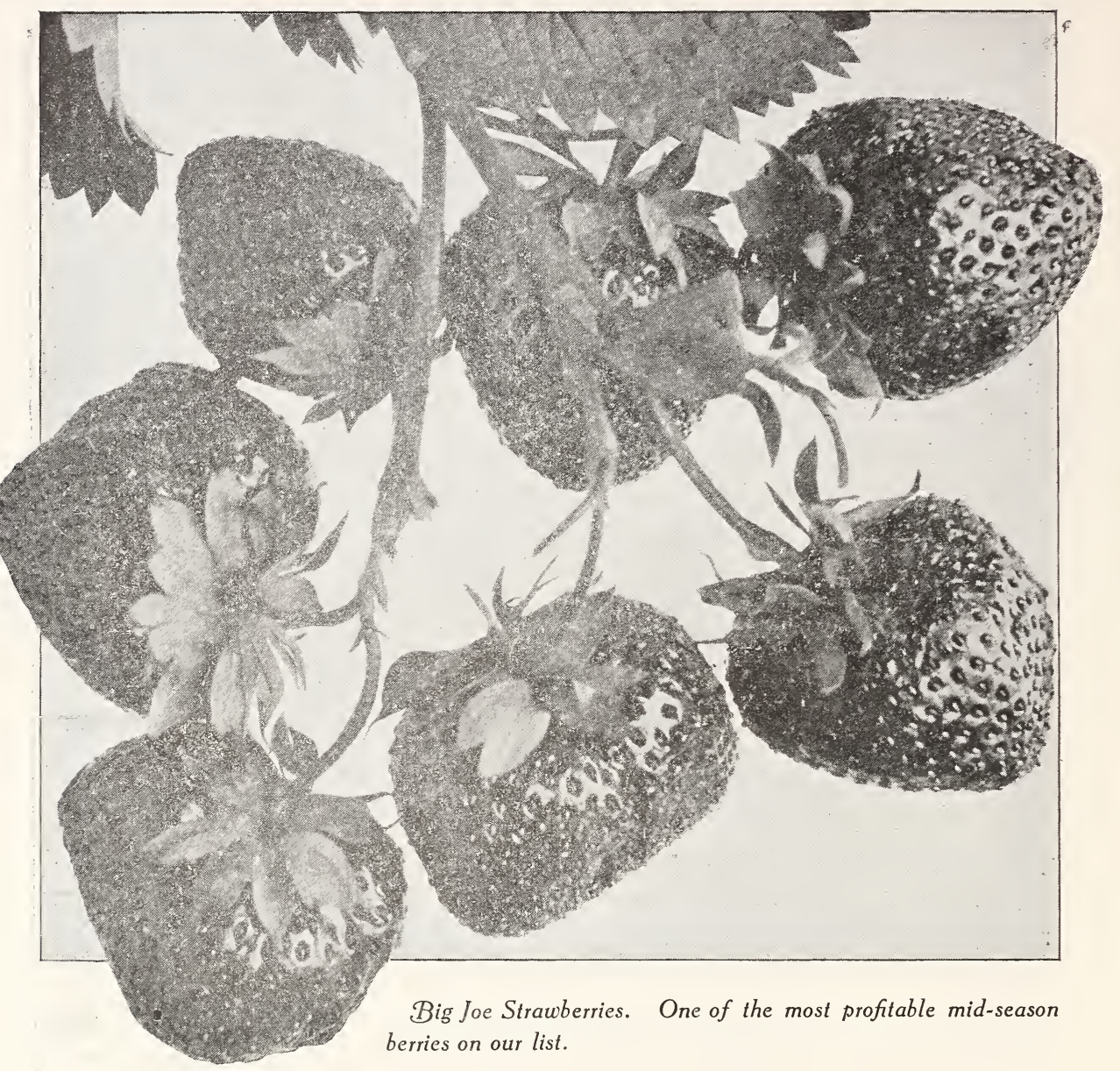

berries on our list.

\section{Warfield}

One of the oldest varieties now grown and still argely planted. Its ability to withstand the most untoward conditions has made it one that can be relied on almost every time. We have never liked it as it always gets so thick on the beds that the berries are too small. It is a very large cropper, and is earlier than most of the midseason kinds.

\section{Wm. Belt}

This has for many years been the standard of excellence so far as quality goes, and we do not know of any that as yet has taken its place. It is a fair grower, but sometimes rusts badly in late summer, and we do not get a good bed. The flavor is so delicious that there is always a demand for more when once it has been placed on the market. It is moderately productive and ripens medium late. 


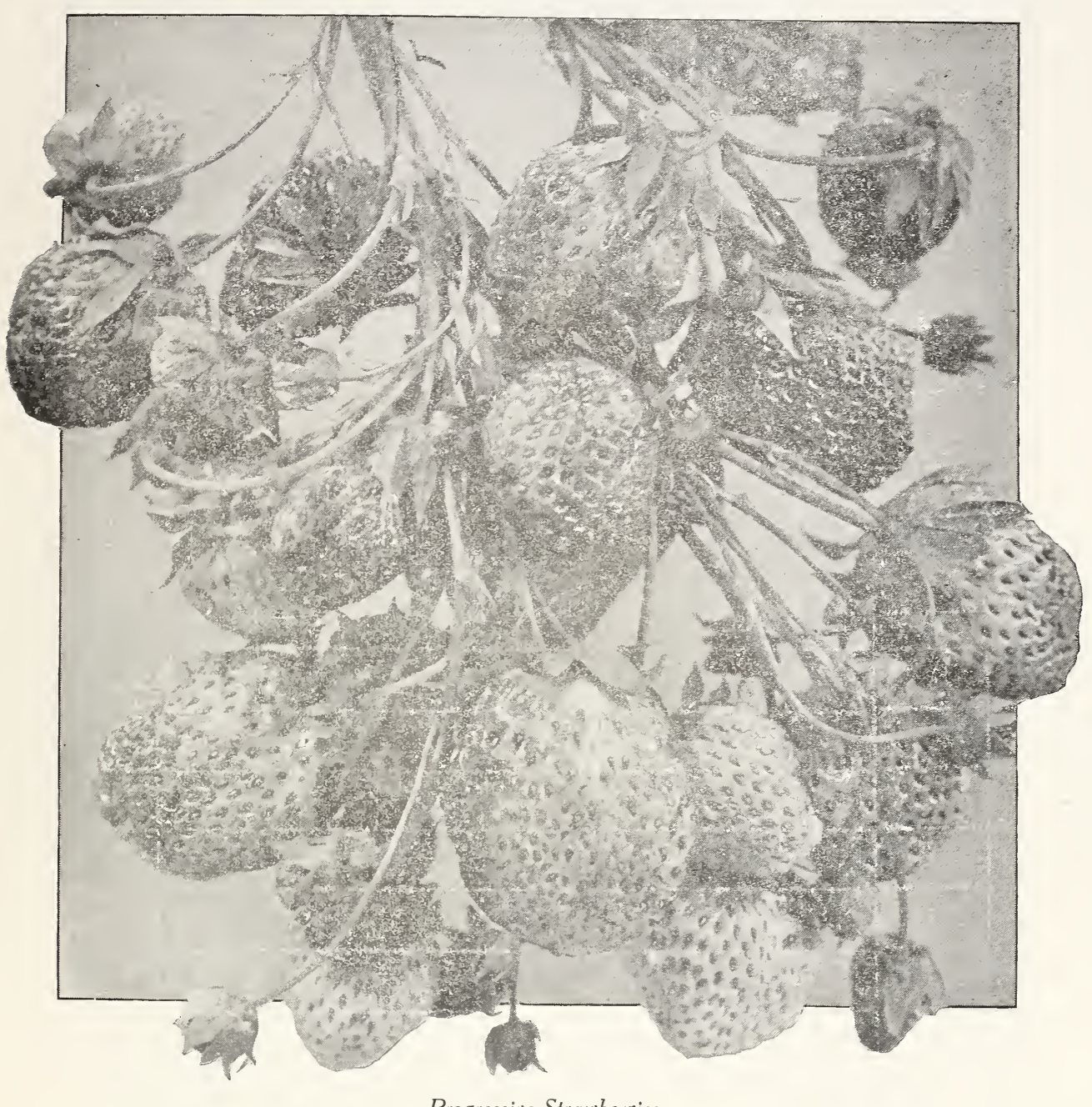

Progressive Strawberries

\section{Fall Bearing Strawberries}

\section{Progressive}

For many years there has been a persistent effort on the part of berry-breeders to secure a summer-bearing Strawberry that was really worth while. Progressive and Superb are real successes. We consider that Progressive is the best for general purpose, for the reason that it will bear freely the same year that it is planted on the current-year plants. That is to say, the runners that take root 
in May and Jure will make a profusion of berries in late August and September. If berries are wanted earlier, the best way is to set the plants close together, say about 12 inches in the row and the rows $2 \frac{1}{2}$ to 3 feet apart, and keep all runners and blossoms cut off until about the 15th of June, when your plants will have made a good start. By the 15th of July you will have on these spring-set plants a profusion of berries. Better-sized berries may be had by this method than by the matted row, but there will not be so many of them. In quality they are in every respect the equal of Wm. Belt or New York, have good color and shape and, if rain is fairly plentiful, they attain a size about equal to Dunlap. The plant is vigorous and healthy in every respect, and makes runners in great profusion. If the early summer is favorable, and you use the matted row system, by August 1st you will have a bed sufficiently wide to produce a good picking of berries three times a week at least. Under ordinary conditions the berries are firm enough to be shipped several hundred miles, and as they come at a time when Strawberries are a luxury the grower is reasonably sure of getting a big price.

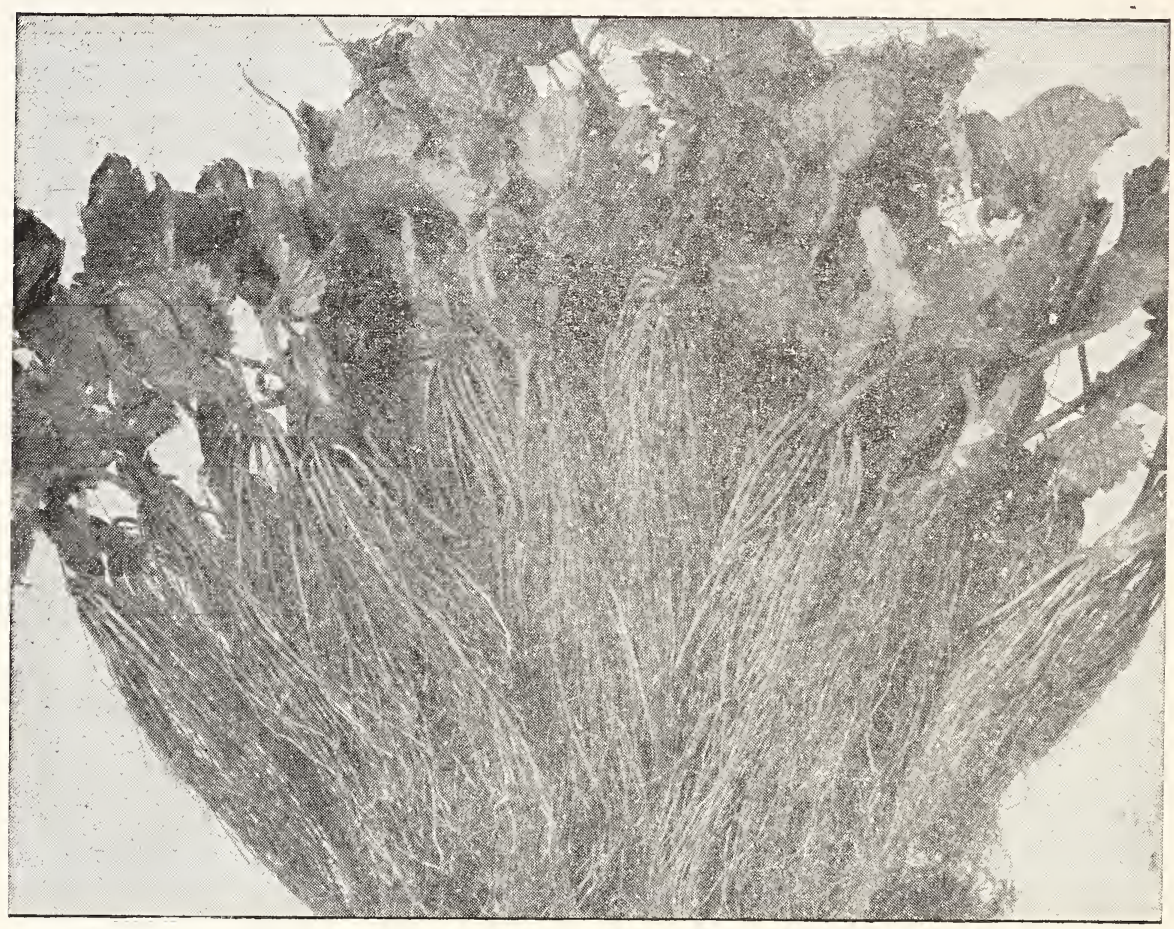

A bunch of our plants opened out showing roots and crowns. You will want this kind

The illustration on page 2 will show the remarkable quality of the roots and crowns of our Strawberry plants. Roots such as there shown insure the health and vigor of the plants, and guarantee that large crops will result if they are given but half a chance. 


\section{J. W. JONES \& SON CO. \\ Growers of Strawberry Plants}

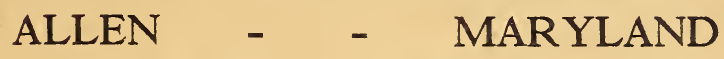

Send to

R. F. D.

Post Office

Box

Ship by .

Shipping Station

County or Street.

State

Date of this order

Ship on or about

Amt. Enclosed-Check $\$ \ldots .$. Money Order $\$ \ldots . .$. Stamps $\$ \ldots . .$. Cash $\$ \ldots .$.

Please write name and address plainly, and ill all blanks perfectly. Always state how goods shall be sent, attach price to each article and add up accurately. Make all letters short and to the point, and please do not write letters on same sheet with the order.

All agreements and contracts are made subject to loss of crop by drought, floods, fire, insects, or other unavoidable causes. All quotations are made subject to stock being sold on receipt of order.-

TRUE TO NAME. While we use every precaution to have all plants, etc., true to name (we believe we come as near doing this as anyone in the business), we will not be responsible for any sum greater than the cost of the stock should any prove otherwise than as represented.-

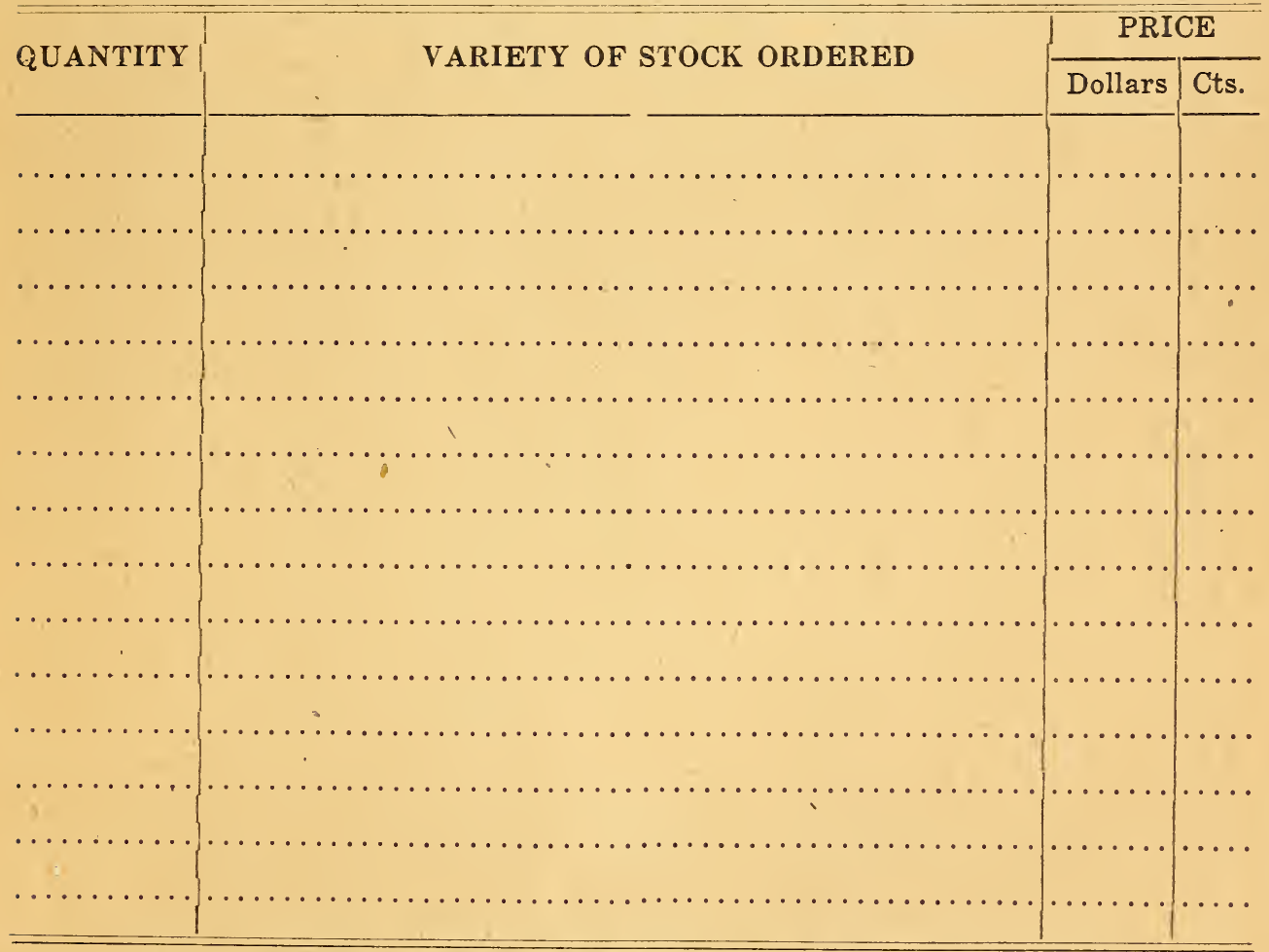

NOTE-Early in the season we usually have in stock everything listed in this catalog, but late in the season we frequently run short of some of the varieties, therefore, when you order late please state whether we shall substitute something equally as good and as near like the variety ordered as possible or rẹturn your money for any stock we may be out of. Answer. 


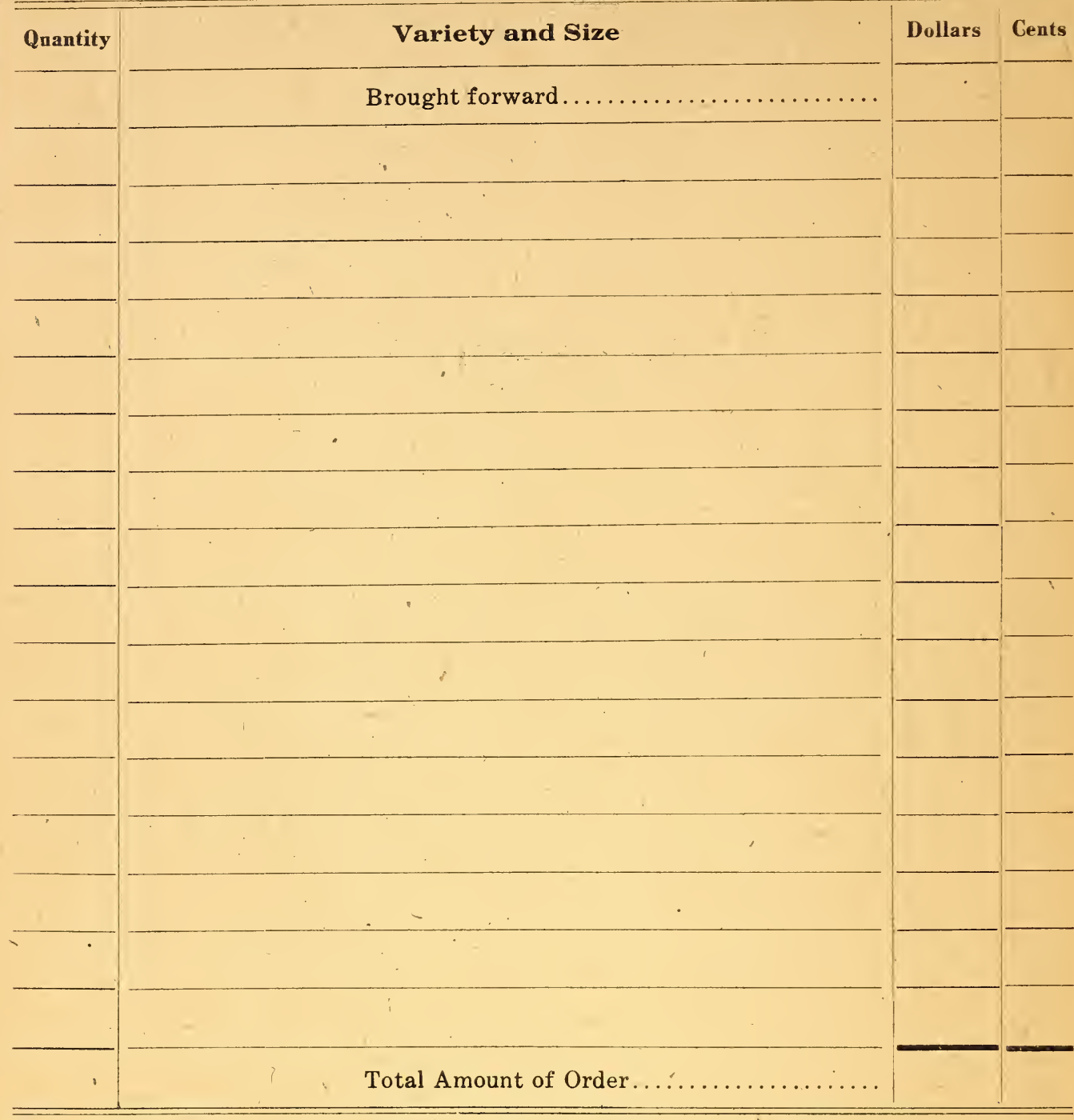

Add proper amount of postage on goods to be shipped by parcel post. If more than is needed is sent the surplus will be promptly returned.

\section{SIEND CATALOG TO YOUR FRIENDS}

We would appreciate it if you would write below the names and addresses of those whom you think might like to receive our catalog.

\section{Name}

Address 


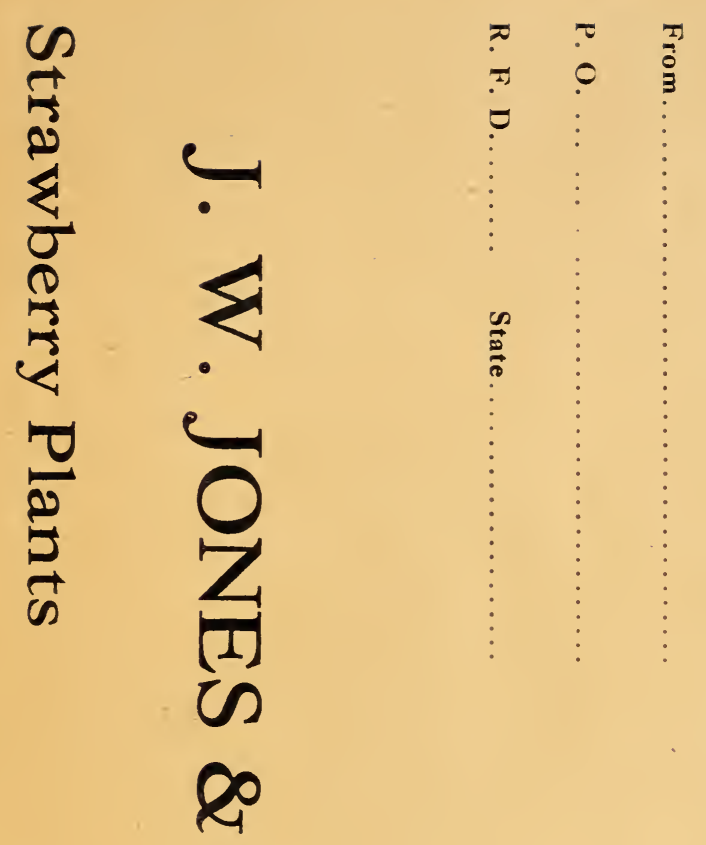

O

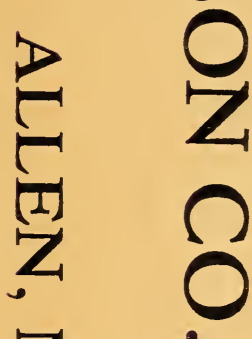

3 


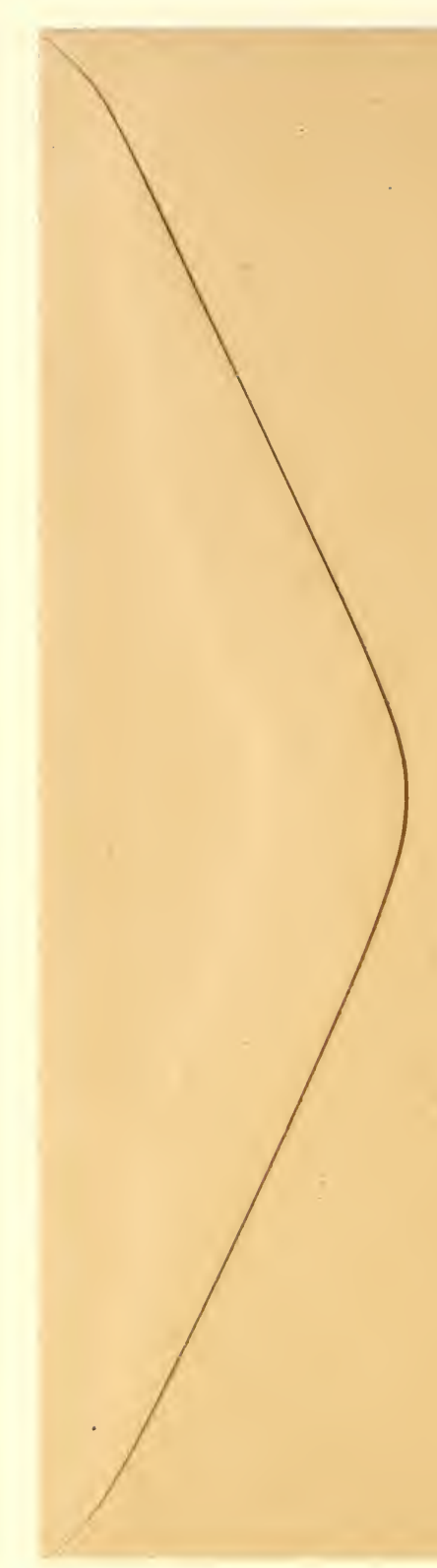




\title{
Price List of Strawberry Plants
}

\author{
BY EXPRESS, RECEIVER TO PAY CHARGES
}

\begin{tabular}{|c|c|c|c|c|c|c|c|c|}
\hline & 3,000 & 1,000 & 500 & 250 & 100 & 50 & 25 & 12 \\
\hline Abington ........... & $\$$ & $\$ 400$ & $\$ 200$ & $\$ 110$ & $\$ 060$ & $\$ 035$ & $\$ 020$ & $\$ 0$ \\
\hline Aroma & 1125 & 400 & 200 & 110 & 60 & 35 & 20 & 1 \\
\hline Big Joe & 1125 & 400 & 200 & 110 & 60 & 35 & 20 & \\
\hline Campbells Early.... & & 400 & 200 & 110 & $6 \tilde{5}$ & 35 & 20 & \\
\hline Chesapeake .............. & & 1000 & 500 & 250 & 110 & 60 & 30 & \\
\hline Dunlap........ & 1125 & 400 & 200 & 110 & 60 & 35 & 20 & \\
\hline Ekey. & 1125 & 400 & 200 & 110 & 60 & 35 & 20 & \\
\hline First-Quality .... & 1125 & 400 & 200 & 110 & 60 & 35 & 20 & \\
\hline Gandy & 1125 & 400 & 200 & 110 & 60 & 35 & 20 & \\
\hline Gibson.... & 1125 & 400 & 200 & 110 & 60 & 35 & 20 & \\
\hline Glen Mary......... & 1125 & 400 & 200 & 110 & 60 & 45 & 25 & \\
\hline Haverland $(\operatorname{Imp}) \ldots \ldots \ldots \ldots$ & 1125 & 400 & 200 & 110 & 60 & 35 & 20 & \\
\hline Improved Heflin. . & & 500 & 250 & 140 & 65 & 35 & 20 & \\
\hline Klondyke ....... & 1000 & 350 & 200 & 110 & 60 & 35 & 20 & \\
\hline Lupt & 1400 & 500 & 200 & 110 & 60 & 35 & 20 & \\
\hline $\mathrm{McA}$ & 1125 & 400 & 200 & 110 & 60 & 35 & 20 & \\
\hline Parsons' Beauty.. & 1125 & 400 & 205 & 110 & 60 & 35 & 20 & \\
\hline Paul Jones. & 1125 & 400 & 200 & 110 & 60 & 35 & 20 & \\
\hline Pren & 1425 & 500 & 250 & 125 & 65 & 35 & 20 & \\
\hline Sample $(\operatorname{Imp}) \ldots \ldots \ldots \ldots$ & 1125 & 400 & 200 & 110 & 65 & 35 & 20 & \\
\hline Warfield $(\operatorname{Imp}) \ldots \ldots \ldots \ldots$ & 1125 & 400 & 200 & 110 & 65 & 35 & 20 & \\
\hline IVm. Belt................ & 1125 & 400 & 200 & 110 & 75 & 40 & 20 & \\
\hline Progressive (Fall) & 2250 & 800 & 400 & 200 & 120 & 75 & 40 & \\
\hline
\end{tabular}

Important. Please note that all varieties are priced in 3,000 lots at a rate lower per thousand than in 1,000 lots. This means that orders will be taken for 3,000 or more of one kind at this lower price, but does not mean that we will accept orders for 3,000 plants of three kinds for $\$ 11.25$ where they are $\$ 4.00$ per thousand. For instance, we will furnish 3,000 Haverland at $\$ 11.25$, but 1,000 each of Haverlnd, Abington and Aroma will be $\$ 12.00$.

However, 4,000 Haverland will be $\$ 15.00,5,000, \$ 18.75$, etc. Customers trying to place orders for less than 3,000 of one variety at the reduced price for 3,000 will find, upon receipt of their plants, that the quantity has been cut down to conform with the money sent.

We Ship Out Only Fresh-dug Plants and will replace free of charge anything that reaches you in bad order, provided the transportation companies have given the shipment reasonable dispatch. If it has been unreasonably long on the way, the purchaser should examine it and, if spoiled, decline tn receive it and make claim on express company. 


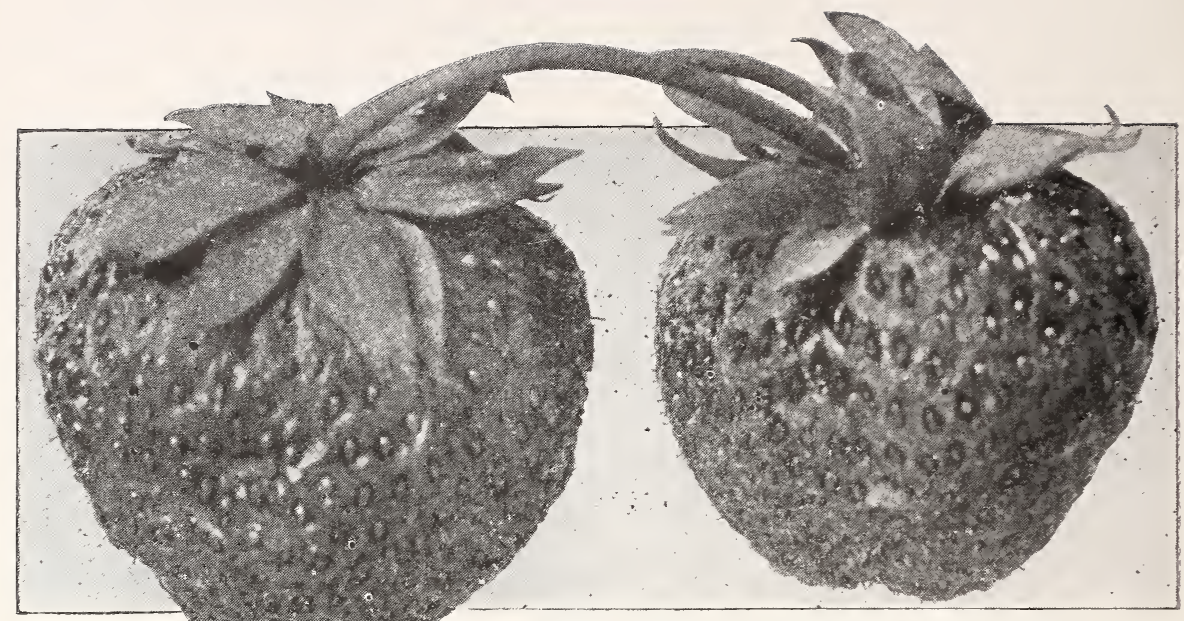

BIG JOE-A wonderful money-maker.

\section{J. W. Jones \& Son Co.}

Growers of Selected Plants of the Best Varieties of STRAWBERRIES

\section{Allen - - - Maryland}

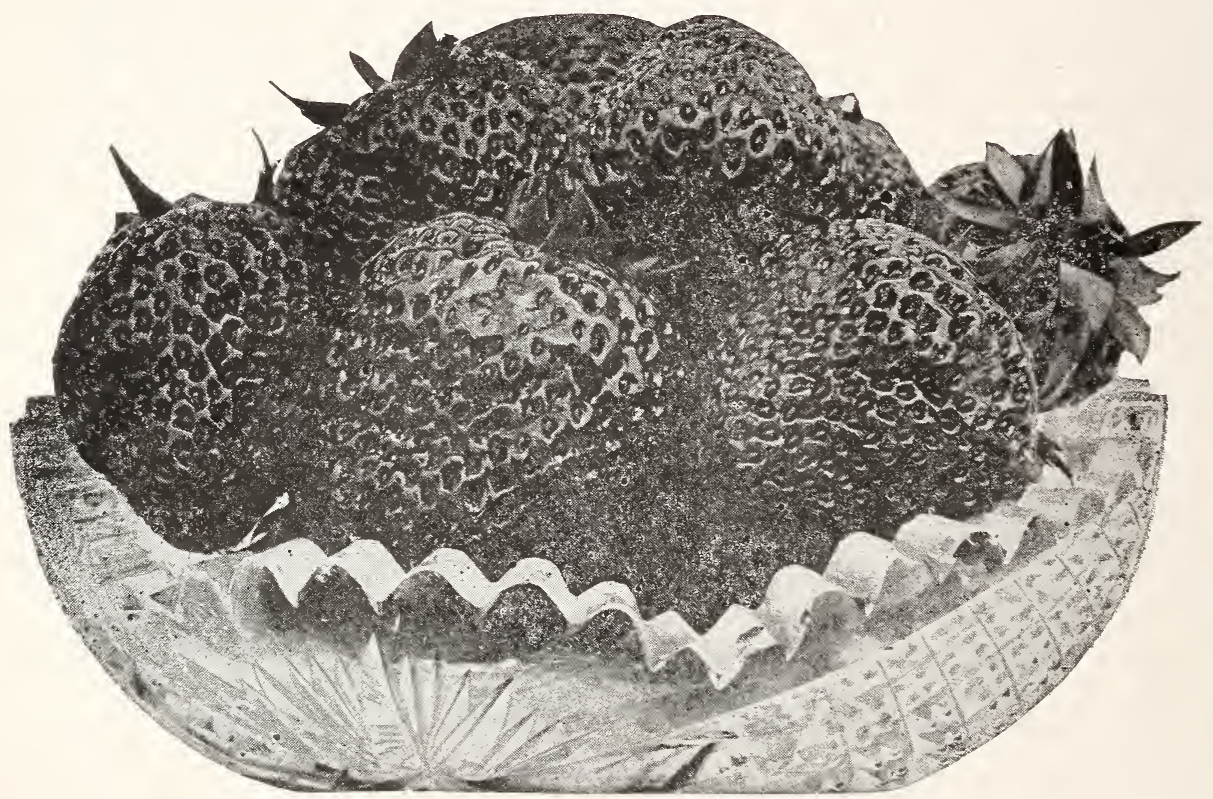

A DISH OF FANCY AROMA 